\title{
FOOD SAFETY IN MARKET ECONOMY
}

\author{
Battalova A.R. \\ Kazan Federal University, \\ Institute of Management, Economics and Finance, \\ Kazan, 420008, Russia \\ Sannikov D.V. \\ Yugra State University, \\ Khanty-Mansiysk, 628011, Russia
}

\author{
Garaeva L.M. \\ Kazan Federal University, \\ Institute of Management, Economics and Finance, \\ Kazan, 420008, Russia \\ Mansurov A.M. \\ Kazan Federal University, \\ Institute of Management, Economics and Finance, \\ Kazan, 420008, Russia
}

\begin{abstract}
Food safety issues are best decided in terms of efficient markets. Dependence on alternative sources exists, but in the case of underproduction by natural disasters (drought, flood, crop failure), even those countries that have a policy of food self-sufficiency are forced to rely on imports. The participants of the economic debate on the issue of the relationship of food self-sufficiency and food security are divided into two sides: the first believe that self-sufficiency is the only guarantee of food security in the long term plan; others rely on the free trade system capable of ensuring long-term food security for all.
\end{abstract} safety.

Keywords- food security, system, self-sufficiency rate, food

\section{INTRODUCTION}

At the time of food safety development it is necessary to ensure the joint targeted and coordinated action of the legislative and executive structures at all levels, to create an appropriate legal framework, to develop an effective organizational and economic mechanism.

In order to resolve food safety issues, the following administrative measures are used: adoption of a system of normative and legal acts; it is necessary to develop and adopt a regional food security strategy at the regional level.

Moreover, taking into account the intention to integrate into the world and European community, one needs to improve the legislative framework in accordance with international standards.

World practice shows that the underestimation of the economic role of the state generates negative consequences. At the same time, one cannot exaggerate the capabilities of the state without recognizing the role of the market economy.

An intelligent synthesis of state regulation and market mechanism solves the main socio-economic problems of the agricultural sector of the country. State intervention in the market economy should be economically justified and acceptable on the scale that enhances economic efficiency [Battalova and Kundakchyan, 2015].
The state is obliged to use its regulatory functions to enhance food market opportunities by eliminating the weaknesses in the domestic market, prevention of external influences, strict control of natural or other monopoly, as well as providing consumers with accurate information about the quantity and quality of food products. Applying regulatory functions, the state and its organs should examine in detail the possibility and effectiveness of various methods of regulatory impact in a particular case [2]

The intention of the country to enter in the international community justify the necessity of a systematic approach to the analysis of contemporary processes of agricultural production development in order to develop appropriate regulatory mechanisms that can ensure a fast adaptation to new conditions of industry management.

Global trends in the context of globalization are related, on the one hand - with the more open markets for food (for developing countries), on the other hand - with targeted measures to ensure food security of every developed nation by implementing protectionist measures.

The complexity of food safety issue necessitates finding ways and mechanisms to ensure it. Developed countries use, as a rule, two basic approaches to food security: the first - the priority support of agricultural producers and the guaranteed maximum of self-sufficiency by all major types of food; the second - the same support for both producers and consumers of food [1].

To ensure food security, one must take into account the relationship between their own products and imported production, the situation of processing industries development, procurement and trade places, food price-making available to the general public and so on. So, in fact, food security covers the entire agro-industrial complex of the country. The inputs are formed in the area of agro-industrial production, respectively, the agro-industrial complex is a guarantor of social and economic stability of society, economic security and independence [5].

On that basis, we have identified key factors of food security (Fig. 1). 
Creating a stable economic environment for the development of agro-industrial complex

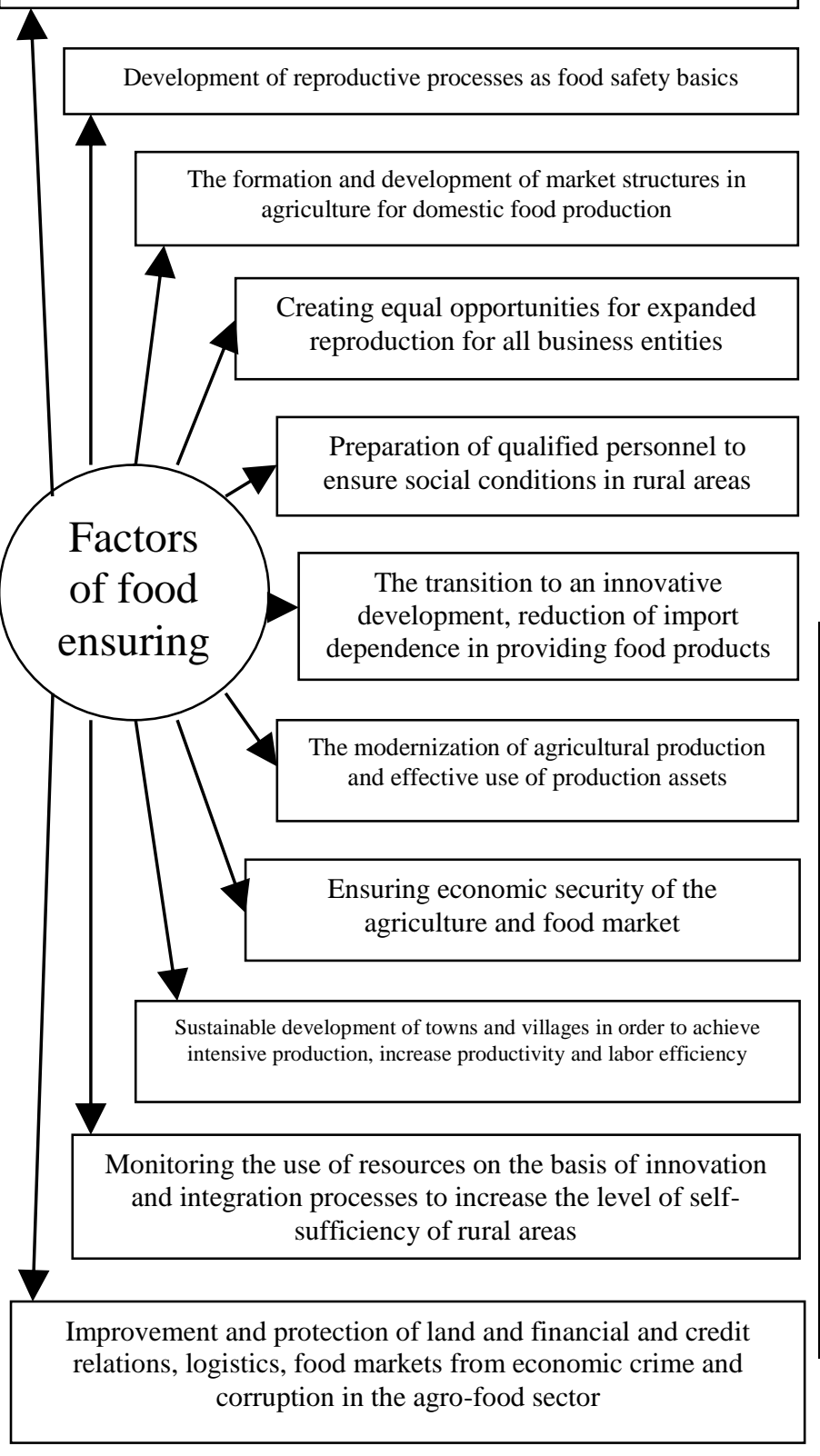

Fig. 1. Socio-economic factors of food security

$$
{ }^{\text {a. }} \text { Source: our own research }
$$

Building an effective food safety system in the economic security systems in modern conditions depends on the analysis of these factors and the correct and timely response to them.

Threats to national interests of the state in ensuring the necessary level of own production of agricultural products, raw materials and food arise from the imbalance of the basic production proportions.

The lack of a systematic approach and the agrarian policy with clear strategic priorities, the imbalance between resource reproduction elements in the agricultural sector have led to an imbalance of social and economic processes of development of the national economy and society [6].
An important part of state regulation of the agriculture system is state support, which is a set of legal, financial, economic, organizational and other measures to stimulate the state influence on the development of both agriculture and rural areas in the right direction for the company.

State support should not be equated with government regulation; the latter can be directed not only to stimulate the development of economic processes, but also their limitation.

\section{METHOD}

One of the general indicators characterizing import substitution is the share of imports of consumer goods and foodstuffs in the volume of retail trade commodity resources. The level and dynamics of this indicator in the Russian Federation for 2005-2015 are shown in Table 1

TABLE I. THE SHARE OF IMPORTS IN THE VOLUME OF RETAIL TRADE COMMODITY RESOURCES IN THE RUSSIAN FEDERATION (\%)

\begin{tabular}{|l|l|l|}
\hline Years & $\begin{array}{c}\text { The share of imported } \\
\text { consumer goods in the retail } \\
\text { trade commodity resources, } \%\end{array}$ & $\begin{array}{c}\text { The share of imported food } \\
\text { products in the retail trade } \\
\text { commodity resources, \% }\end{array}$ \\
\hline 2005 & 45 & 36 \\
\hline 2006 & 46 & 35 \\
\hline 2007 & 47 & 36 \\
\hline 2008 & 44 & 33 \\
\hline 2009 & 41 & 33 \\
\hline 2010 & 44 & 34 \\
\hline 2011 & 43 & 33 \\
\hline 2012 & 44 & 34 \\
\hline 2013 & 44 & 36 \\
\hline 2014 & 42 & 34 \\
\hline 2015 & 38 & 28 \\
\hline
\end{tabular}

\section{RESULT}

The analysis shows that the share of imports of consumer goods and foodstuffs in the volume of retail trade commodity resources in the 2005-2013 is relatively stable, while, since 2008 there is a trend of slow decline of this indicator. In 2015, in connection with the recent developments in the global political stage the share of import begins to decline sharply. This trend positively characterizes the process of import substitution during the growth or maintaining the level of consumption of these products [10].

Further, more detailed analysis shows the dynamics of change in the share of certain goods imported into their commodity resources in the Russian Federation. The results are given in Table 2.

The analysis showed that the majority of goods items decrease in the share of imports in the implementation of the relevant commodity resources, which confirms our earlier 
conclusion concerning the positive dynamics of their import [8].

TABLE II. THE SHARE OF IMPORT OF CERTAIN GOODS IN THEIR COMMODITY RESOURCES IN THE RUSSIAN FEDERATION $(\%)$

\begin{tabular}{|c|c|c|c|c|c|c|c|c|}
\hline $\begin{array}{c}\text { Groups of } \\
\text { goods }\end{array}$ & 2008 & 2009 & 2010 & 2011 & 2012 & 2013 & 2014 & 2015 \\
\hline $\begin{array}{l}\text { Meat and } \\
\text { poultry meat, } \\
\text { including } \\
\text { organ meat }\end{array}$ & 43,8 & 38,2 & 33,7 & 30,0 & 30,3 & 26,2 & 19,8 & 13,4 \\
\hline $\begin{array}{l}\text { Pork, } \\
\text { including } \\
\text { organ meat }\end{array}$ & 61,7 & 61,8 & 64,5 & 59,5 & 59,9 & 59,0 & 57,3 & 50,6 \\
\hline $\begin{array}{l}\text { Beef, } \\
\text { including } \\
\text { organ meat }\end{array}$ & 56,5 & 41,6 & 46,8 & 42,8 & 41,3 & 31,0 & 16,6 & 12,2 \\
\hline $\begin{array}{l}\text { Poultry meat, } \\
\text { including } \\
\text { organ meat }\end{array}$ & 33,3 & 26,1 & 18,2 & 12,5 & 14,0 & 12,8 & 10,2 & 5,7 \\
\hline Canned meat & 18,8 & 16,5 & 17,1 & 22,0 & 25,1 & 20,0 & 13,7 & 6,8 \\
\hline $\begin{array}{l}\text { Sausage } \\
\text { products }\end{array}$ & 1,1 & 1,3 & 1,3 & 1,7 & 3,4 & 3,2 & 2,2 & 1,1 \\
\hline Tallow oil & 27,0 & 27,1 & 32,3 & 32,2 & 34,2 & 35,9 & 34,4 & 25,5 \\
\hline Cheese & 41,3 & 41,2 & 47,4 & 46,1 & 47,8 & 48,0 & 37,3 & 22,6 \\
\hline Flour & 0,2 & 0,1 & 0,9 & 1,0 & 0,7 & 1,5 & 0,9 & 0,6 \\
\hline Groats & 4,2 & 2,1 & 2,2 & 2,0 & 1,4 & 1,8 & 0,5 & 0,3 \\
\hline Vegetable oil & 31,2 & 18,5 & 23,9 & 22,0 & 16,3 & 19,0 & 14,7 & 17,5 \\
\hline $\begin{array}{l}\text { Dry milk and } \\
\text { cream }\end{array}$ & 30,0 & 37,3 & 60,1 & 40,7 & 48,4 & 60,5 & 49,5 & 54,0 \\
\hline $\begin{array}{l}\text { Confectioner's } \\
\text { goods }\end{array}$ & 10,3 & 6,8 & 11,1 & 11,6 & 12,5 & 12,0 & 9,4 & 7,5 \\
\hline Sugar & 2,7 & 4,8 & 5,4 & 3,7 & 5,3 & 8,2 & 7,4 & 6,2 \\
\hline
\end{tabular}

A rapid decline in the share of imports in commodity resources can be traced for such products as meat, sausage products, canned meat, oil, cheese. Only in such commodity groups as vegetable oil, dry milk and cream there is an increase in the share of imports relative to their commodity resources.

\section{FINDINGS}

Indeed, the current state of agricultural development is unbalanced, and the problem of food security is constantly aggravated. One of the causes of this situation is that agriculture (the main supplier of raw materials for industrial processing in the food) became dependent on too high, economically unjustified prices of industrial origin of the resources, and too low prices for produced agricultural products [11].

Such pricing policy contributes to, in turn, curtailment of production, which is central to the national diet - milk, meat, fruits, vegetables and re-release of highly liquid products corn, sunflower, and rapeseed. In addition, the problem of raw material supply of process industry flow from the irrational structure of the agricultural sector, in which more than $60 \%$ of the gross production of the population belongs to households [9].

The fact that the food security of the population depends primarily on the development of the agricultural sector, which directly creates the material foundation of human life, indicates the priority and necessity of state support of this particular sector. As known, our country is on the path of market methods of management, significant advantages are confirmed by international experience, and therefore it is necessary to use them rationally. The current stage of the evolutionary development of society is characterized by the operation of a regulated market economy. Unfortunately, over the past decades, one has not been able to develop and implement a comprehensive and effective system of state regulation in the agricultural sector [7].

\section{DisCUSSIONS}

Agriculture lags behind in the development of other sectors of the economy. The backlog of agriculture of the main contractors in the economic development worsens its position, causing an even greater lack of access to services industry, trade, transport and finance to the agricultural sector. The main reason for this disparity in the development of industries consists in agricultural features. Firstly, seasonality and slow rotation of capital in production causes a delayed reaction to changes in prices in the economy. Secondly, the rate of deterioration of the final products of the agrarian sector forces to implement them at purchasers' prices. Livestock industry is in a worse condition. It needs public support through adequate budgetary subsidies on products. The branch will be able to work effectively and to refuse this assistance only when market prices provide the management of profitable production, and the purchasing power of the population will allow one to buy expensive products [7].

The development of the food industry is due to the situation in agricultural production. The distance of raw areas from processing centers, the poor harvesting network in rural areas, a rise in price of gasoline and diesel fuel, shortage of raw materials affected the reduction in the volume of output; processors found themselves in financial difficulty, the technical level of processing enterprises decreased [4]. Currently, the main factors that prevent the enterprises of food and processing industries increase profitability have arrived mass sufficient to create the necessary accumulation fund to ensure the expanded reproduction of fixed assets (their modernization and technical re-equipment) and working capital financing to the extent necessary for the ensure continuous production of products are: a reduction in agricultural production, the high tax burden, the rise in price of energy and transport services.

\section{CONCLUSION}

At the time of food safety development it is necessary to ensure the joint targeted and coordinated action of the legislative and executive structures at all levels, scientific and financial institutions, industrialists and businessmen. To do 
this, one must create an appropriate legal framework, to develop an effective organizational and economic mechanism.

\section{References}

[1] A.R. Battalova, G.R. Faizrahmanova, Evaluation of food security in the region on the basis of performance in the field of production (Volga Federal District case study), Journal of Economics and Economic Education Research, 2016, v.17, № 2, pp. 263-269.

[2] A.R. Battalova, R.M. Kundakchyan, A.M. Tufetulov, Z.N. Zapparova: Necessity and perspectives of formation of the state of food security, Journal of Economics and Economic Education Research, 2016, v.17, no. 3, pp. 1-7.

[3] A.R. Battalova, R.M. Kundakchyan, The problem of food security in Russia, Mediterranean Journal of Social Sciences, 2015, v.6, № 3, pp. 773-776.

[4] L.F. Garifova, R.M. Kundakchyan, Pratchenko O.V. Integrated assessment of the impact of socio-ecological-economic factors on the quality of life of the population of the region, Mediterranean Journal of Social Sciences, vol 5, June 2014, pp.117-121.

[5] E.A. Hanushek, D. Kimko, Schooling, Labor Force Quality, and the Growth of Nations, American Economic Review, 2000, No. 90, pp. $1184-1208$.

[6] S. Huning, M. Naumann, O. Bens, R.F. Hüttl, Transformations of modern infrastructure planning in rural regions: The case of water infrastructures in Branden-burg, Germany, European Planning Studies, 19 (8), 2011, pp. 1499-1516

[7] O.A. Ignateva, I.I. Abdullin, Problem of the informative making vaguenessof economic environment as feature of national market, Procedia Economics and Finance, no. 24, 2015, pp. 345-349.

[8] N.M. Sabitova, C.M. Shavaleyeva, E.N. Nikonova, Horizontal imbalances of Russian federation budget system. Asian Social Science, 2015, 11(11s), 248-252.

[9] L.N. Safiullin, G.N. Ismagilova, N.Z. Safiullin, N.G. Bagautdinova, The de-velopment of welfare theory in conditions of changes in the quality of goods and ser-vices, World Applied Sciences, 2012, Journal 18, pp. 144149.

[10] A.M. Safiullina, M.E. Ivanov, A.V. Ramazanov, The Forms and the Methods of State Influence on the Innovation Climate Factors (On The Example of the Russian Federation and the Tatarstan Republic), Mediterranean Journal of Social Sciences, Vol. 5, № 18, 2014.

[11] N. Velenteichyk, Congruence of interests of the center and regions in the course of intergovernmental relations regulation, Economic 183, AnnalsXXI, 2013, 5-6(2), 37-40. 